\title{
TERAPI TRANSPLANTASI SEL PUNCA SEBAGAI UPAYA PELAYANAN KESEHATAN DI INDONESIA DALAM PERSPEKTIF HUKUM KESEHATAN DAN HUKUM ISLAM
}

\author{
Alya Tursina \\ Alumni Magister Ilmu Hukum Pascasarjana Unisba \\ (Dosen Tetap Fakultas Kedokteran Unisba) \\ e-mail : alyanuryadin@gmail.com
}

\begin{abstract}
Abstrak- Kemajuan ilmu pengetahuan dan teknologi kedokteran dewasa ini sangat berkembang, diantaranya terapi transplantasi sel punca sebagai harapan baru untuk mengobati berbagai penyakit yang sudah tidak dapat diobati lagi secara konservatif maupun operatif. Dalam mengembangkan transplantasi sel punca sebagai penyembuhan suatu penyakit harus sesuai dengan hukum kesehatan yang berlaku, bioetik, moral dan agama khususnya hukum Islam. Di Indonesia, status penggunaan sel punca masih menimbulkan kontroversi karena belum adanya regulasi yang jelas. Tujuan penelitian ini adalah untuk mengetahui hukum kesehatan saat ini sudah memadai atau belum dalam pelaksanaan terapi transplantasi sel punca sebagai upaya pelayanan kesehatan di Indonesia dan pandangan hukum Islam terhadap hal tersebut. Penelitian ini menggunakan pendekatan yuridis normatif, dengan sumber data utama adalah data sekunder. Penelitian disusun secara deskriptif kualitatif. Terhadap masalah yang diteliti yaitu kebijakan hukum, bioetika dan hukum Islam dalam pelaksanaan terapi transplantasi sel punca serta hal-hal yang berkaitan dengan masalah tersebut dilakukan pengkajian dengan berpedoman pada peraturan perundang-undangan yang berlaku. Hasil penelitian ini menunjukkan bahwa penggunaan terapi transplantasi sel punca hanya dapat dilakukan untuk tujuan penyembuhan penyakit dan pemulihan kesehatan, serta dilarang digunakan untuk tujuan reproduksi dengan menggunakan sel punca yang berasal dari non embrionik. Sel punca tidak boleh berasal dari sel punca embrionik. Pelaksanaan terapi transplantasi sel punca menurut hukum Islam pada dasarnya harus dapat memelihara kepentingan hidup dengan menjaga dan memelihara kemashlahatan manusia.
\end{abstract}

\section{Kata kunci : Sel Punca, Hukum Kesehatan, Hukum Islam}

Abstract- Advances in medical science and technology today are highly developed, including stem cell transplantation therapy as a new hope for treating various diseases that can no longer be treated conservatively or operatively. In developing stem cell transplantation as a cure for a disease, it must be following applicable health, bioethical, moral, and religious laws, especially Islamic law. In Indonesia, the status of stem cell use still causes controversy because there is no clear regulation. This study aimed at finding out whether current health law is adequate in the implementation of stem cell transplantation therapy as an effort to provide health services in Indonesia and the view of Islamic law on it. This study used normative juridical approach with the primary data source is secondary data. The study was arranged in a descriptive qualitative method based on the applicable laws and regulation regarding the problem under study, namely legal policy, bioethics, and Islamic law in the implementation of stem cell transplantation therapy and matters relating to the problem.. The result indicates that the use of stem cell transplantation therapy can only be conducted for healing disease and health recovery, and is forbidden to be used for reproductive purposes by using stem cells originating from non-embryonic. Stem cells must not originate from embryonic stem cells. The implementation of stem cell transplantation therapy according to 
Alya Tursina, Terapi Transplantasi Sel Punca Sebagai Upaya Pelayanan Kesehatan Di Indonesia Dalam...

Islamic law basically must be able to preserve the interests of life by protecting and preserving human welfare.

Keywords: Stem Cell Transplantation, Health Law, Islamic Law

\section{A. PENDAhULUAN}

Kesehatan merupakan salah satu hak dasar manusia yang fundamental dan unsur penting dari kesejahteraan. Di dalam UUD 1945 Pasal $28 \mathrm{H}$ ayat (1) secara jelas dinyatakan bahwa setiap orang berhak hidup sejahtera lahir dan batin, bertempat tinggal, dan mendapatkan lingkungan hidup yang baik dan sehat serta berhak memperoleh pelayanan kesehatan. Secara filosofis, kesehatan adalah hak setiap manusia, dan merupakan kewajiban negara untuk memenuhi hak tersebut terutama pada situasi, ketika seseorang tidak mendapatkan kesempatan yang sama untuk menikmati haknya itu. Hal ini merupakan isu keadilan, dengan adanya hubungan erat antara isu kesehatan, keadilan dan hak asasi manusia, maka dengan sendirinya fungsi hukum menjadi sangat vital. ${ }^{1}$

Tujuan pembangunan kesehatan merupakan bagian integral dari pembangunan nasional dinyatakan dalam Undang-Undang RI No. 36 Tahun 2009 tentang Kesehatan yaitu untuk

\footnotetext{
${ }^{1}$ Sartika Sasmi Ticoalu, Tanggung Jawab Pemerintah Dalam Memberikan Pelayanan Kesehatan Terhadap Masyarakat, Lex et Societatis, Vol. I/No. 5/September/2013, hal. 154
}

meningkatkan kesadaran, kemauan, dan kemampuan hidup sehat bagi setiap orang agar terwujud derajat kesehatan masyarakat yang setinggi-tingginya, sebagai investasi bagi pembangunan sumber daya manusia yang produktif secara sosial dan ekonomis.

Hermien Hadiati Koeswadji menyatakan pada asasnya hukum kesehatan bertumpu pada hak atas pemeliharaan kesehatan sebagai hak dasar social (the right to health care) yang ditopang oleh 2 (dua) hak dasar individual yang terdiri dari hak atas informasi (the right to information) dan hak untuk menentukan nasib sendiri (the right of self determination). ${ }^{2}$ Hak dasar manusia inilah yang lazim dikenal sebagai hak asasi manusia bertolak dari idea yang berfokus pada manusia sebagai individu dalam mencapai tujuan pokok dari hidup manusia.

Black's Law Dictionary, 1979 menguraikan pengertian dan ruang lingkup hukum kesehatan sebagai berikut : "Health law is laws ordinances or codes prescribing sanitary standards and

2 Hermien Hadiati Koeswadji, Hukum Kedokteran, Studi Tentang Hubungan Hukum Dalam Mana Dokter Sebagai Salah Satu Pihak, PT. Citra Aditya Bakti, Bandung, 1998, hlm 22. 
Alya Tursina, Terapi Transplantasi Sel Punca Sebagai Upaya Pelayanan Kesehatan Di Indonesia Dalam...

regulations, designed to promote and reserve the health of the community."

Maksud hukum kesehatan menurut Black Law Dictionary tersebut adalah seperangkat hukum, ordonansi ataupun peraturan yang mengatur tentang standar kebersihan dan kesehatan, yang dibentuk untuk menjaga dan melestarikan kesehatan masyarakat. $^{3}$

Penggunaan sel punca untuk mengobati penyakit dikenal sebagai terapi berbasis sel atau cell based therapy. Sel punca saat ini menjadi pusat perhatian peneliti dunia karena manfaatnya yang besar. Menteri Kesehatan Republik Indonesia, Nila Farid Moeloek menyampaikan bahwa peneliti Indonesia juga sudah harus mulai bergerak dibidang terapi sel punca dan untuk mendapatkan produk informasi dan inovasi yang valid dan terpercaya, maka para peneliti kita sebelumnya harus melakukan penelitian dan pengembangan kesehatan yang terjaga mutunya secara ilmiah maupun secara etik. Produk informasi dan inovasi tersebut, juga sangat berguna dalam

3 Syahrul Machmud, Penegakan Hukum dan Perlindungan Hukum bagi Dokter yang diduga Melakukan Medikasi Malpraktek, Cetakan 1, CV Mandar Maju, Bandung, 2008, hlm 7. rangka pengambilan keputusan berbasis bukti (evidence based policy). ${ }^{4}$

Pemerintah sebagai penyelenggara negara, bertanggung jawab atas ketersediaan sumber daya di bidang kesehatan, ketersediaan segala bentuk upaya kesehatan yang ditujukan kepada masyarakat secara adil dan merata, dalam hal ini pemerintah juga bertanggung jawab dalam pelayanan kesehatan sebagai salah satu bagian yang tidak terpisahkan dalam pembangunan kesehatan. Pengembangan dalam pelayananan kesehatan terapi sel punca membutuhkan regulasi yang ketat dan harus sesuai dengan norma-norma serta etika yang berlaku di Indonesia untuk menghindari penyalahgunaan. Dalam Undang-Undang RI No 36 tahun 2009 tentang kesehatan pasal 66 disebutkan bahwa "Transplantasi sel, baik yang berasal dari manusia maupun dari hewan, hanya dapat dilakukan apabila telah terbukti keamanan dan kemanfaatannya".

\footnotetext{
${ }^{4}$ Nila Farid Moeloek, Menteri Kesehatan RI, dalam pidato Pembukaan Simposium Internasional ke-2 Penelitian dan Pengembangan Kesehatan: Basic Research and Innovation Breakthrough into Product, Publikasi dari Pusat Komunikasi Publik Sekretariat Jenderal Kementerian Kesehatan RI Selasa 15 Sepember 2015 di Jakarta. www.depkes.go.id diunduh 20 Desember 2015 pukul 08.00
} 
Alya Tursina, Terapi Transplantasi Sel Punca Sebagai Upaya Pelayanan Kesehatan Di Indonesia Dalam...

Sel punca menimbulkan kontroversi dari sisi etika di luar potensinya yang begitu hebat. Namun demikian, karena sifat dan potensinya terapi sel punca rawan digunakan secara salah sehingga perlu adanya regulasi yang jelas dari pemerintah baik untuk para peneliti, tenaga medis maupun masyarakarat sebagai penerima pelayanan agar dapat memanfaatkan kemajuan teknologi terapi sel punca dengan penuh tanggung jawab demi kemaslahatan umat manusia. Dalam penelitian dan pengembangan serta penerapan terapi sel punca ada beberapak aspek yang menjadi pedoman pelaksanaannya yaitu aspek ilmiah, aspek etika, legal dan dampak sosial bagi masyarakat. $^{5}$

Indonesia sebagai Negara hukum mengakui keberadaan hukum Islam baik secara yuridis konstitusional, yuridis formal dan normatif. Hukum Islam secara yuridis konstitusional didasarkan pada pasal 29 ayat (1) Undang-Undang Dasar 1945 yang menyatakan "Negara berdasarkan atas ketuhanan Yang Maha Esa". Hazairin menafsirkan pasal tersebut bahwa dalam Negara Republik Indonesia, tidak boleh terjadi atau berlaku sesuatu

5 Amin Soebandrio, Pedoman Riset Sel Punca Manusia, Edisi Pertama, Asosiasi sel Punca Indonesia, Jakarta, 2010, hlm 1. yang bertentangan dengan kaidah-kaidah Islam bagi umat Islam, begitu juga bagi umat lain. ${ }^{6}$

Al-Qur'an dan As-Sunnah merupakan sumber hukum utama dalam agama Islam, segala hal yang menyangkut kehidupan termasuk kesehatan, sains dan teknologi secara umum terdapat dalam Al-Qur'an dan As-Sunnah.

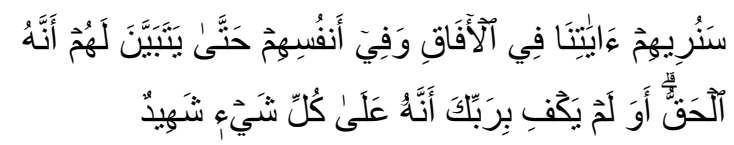

"Kami akan memperlihatkan kepada mereka tanda-tanda (kekuasaan) Kami di segala wilayah bumi dan pada diri mereka sendiri, hingga jelas bagi mereka bahwa Al Quran itu adalah benar. Tiadakah cukup bahwa sesungguhnya Tuhanmu menjadi saksi atas segala sesuatu" (QS Al Fushilat : 53)

Rasulullah s.a.w. bersabda:

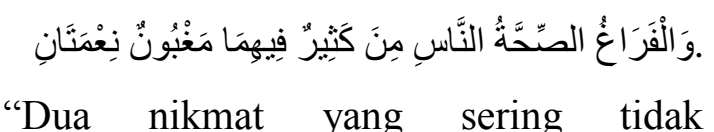
diperhatikan oleh kebanyakan manusia yaitu kesehatan dan waktu luang." (Hadis Riwayat al-Bukhari dari Ibnu Abbas) Hukum dalam perspektif Islam memiliki dua dimensi. Pertama, dimensi tsubut, yakni syariat yang bersifat universal dan

\footnotetext{
${ }^{6}$ Suparman Usman, Hukum Islam Asasasas dan Pengantar Studi Hukum Islam dalam Tata Hukum Indonesia, Gema Media Pratama, Cetakan ke-2, Jakarta, 2002, hlm 4.
} 
Alya Tursina, Terapi Transplantasi Sel Punca Sebagai Upaya Pelayanan Kesehatan Di Indonesia Dalam...

menjadi asas pemersatu aktivitas umat Islam sedunia. Kedua dimensi taghayyur yakni produk pemikiran manusia dalam memahami syari'at (Ijtihad) yang disebut fiqh. Dimensi kedua ini yang memberikan kemungkinan perbedaan hukum bahwa setiap wilayah yang dihuni umat Islam dapat menerapkan hukum Islam secara berbeda-beda, karena perbedaan latar belakang politik, sejarah, sosiologis dan kulturalnya masingmasing. Disinilah Ijtihad menjadi sebuah keniscayaan dalam arti upaya menterjemahkan pesan-pesan universal syariat sehingga menjadi suatu konfigurasi hukum yang mampu menjawab problematika hukum yang

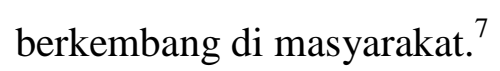

Globalisasi dengan berbagai aspeknya menuntut hukum Islam untuk mampu menjawab berbagai persoalan hukum yang sebelumnya tidak ada. Hubungan antara teori hukum dan perubahan masyarakat di era globalisasi merupakan suatu persoalan essensial dalam filsafat hukum. Menteri Agama RI, Suryadharma Ali menegaskan bahwa fatwa dapat

\footnotetext{
${ }^{7}$ Maskun, Problematika Aplikasi Produk Pemikiran Hukum Islam di Indonesia, dalam Jurnal Bulanan Mimbar Hukum N0. 49, Al Hikmah Ditbinbapera Islam, Jakarta, 2000, hlm 38.
}

menjadikan Islam shalihun li kulli zaman wa makan (sesuai dengan perkembangan situasi dan kondisi zaman). "Fatwa merupakan khazanah intelektual Islam yang sangat khas dan berfungsi secara baik hingga sekarang. Terkait beberapa fenomena perubahan sosial yang terjadi dan membutuhkan fatwa untuk memberikan kepastian hukumnya, fatwa akan selalu hadir tepat waktu dengan substansi yang sesuai kebutuhan masyarakat Muslim.”

Para ulama telah menyusun seperangkat metodologi untuk menafsirkan ayat-ayat dan hadis dalam upaya lebih mendekatkan pada maksud-maksud pensyariatan hukum di satu pihak dan mendekatkan hasil penalaan dengan kenyataan yang ada di tengah masyarakat di pihak lain. Kerangka sistematis kaidah-kaidah tersebut, mula-mula diperkenalkan oleh Imam al-Syafi'i (150-204 H). Secara umum metode penalaran tersebut dapat dibagi ke dalam tiga pola, yaitu pola bayani (kajian semantik), pola ta'lili (penentuan 'illat), dan pola istishlahi (pertimbangan kemaslahatan berdasar nash umum).

${ }^{8}$ Suryadharma Ali, Menteri Agama RI, dalam pidato Pembukaan, International Conference on Fatwa, Jakarta, 24 - 26 Desember 2012 . www.kemenag.go.id diunduh 20 Januari 2016 pukul 21.00 
Salah satu sumber sel punca yang dipermasalahkan adalah sel embrionik. Sel punca embrionik dapat tumbuh menjadi berbagai tipe sel di dalam tubuh, kecuali sel telur dan sperma. Dengan kemampuannya, sel punca embrionik merupakan jenis yang paling fleksibel untuk digunakan. Namun, inilah pokok masalah tersebut penelitian sel punca embrionik manusia dianggap melanggar batas etika karena untuk memulai membuat galur sel punca (line stem cell), maka biasanya akan mengorbankan embrio manusia.

Apa yang bisa di capai dengan teknologi belum tentu bisa di terima oleh agama dan hukum yang hidup di masyarakat. Terapi transplantasi adalah masalah yang ijtihadi karena tidak ada hukumnya secara eksplisit di dalam al-Qur'an dan Hadits dan juga merupakan masalah yang cukup kompleks menyangkut berbagai bidang studi maka seharusnya masalah ini di analisis dengan menggunakan metode pendekatan multidisplainer, seperti kedokteran, biologi, hukum, etika, dan agama agar dapat di peroleh kesimpulan hukum ijtihadi yang proporsional dan mendasar.

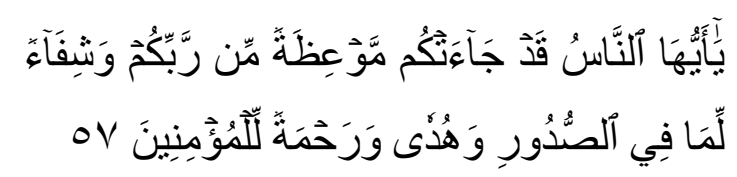

"Hai manusia, sesungguhnya telah datang kepadamu pelajaran dari Tuhanmu dan penyembuh bagi penyakit-penyakit (yang berada) dalam dada dan petunjuk serta rahmat bagi orang-orang yang beriman." (QS:Yunus 57).

Rasulullah Saw bersabda:

"Sesungguhnya Allah telah menurunkan penyakit dan obatnya, demikian pula Allah menjadikan bagi setiap penyakit ada obatnya. Maka berobatlah kalian dan janganlah berobat dengan yang haram.” (HR. Abu Dawud dari Abud Darda` radhiallahu 'anhu)

Imam Ahmad telah meriwayatkan hadits dari Anas Ra yang telah berkata, bahwa Rasulullah Saw bersabda:

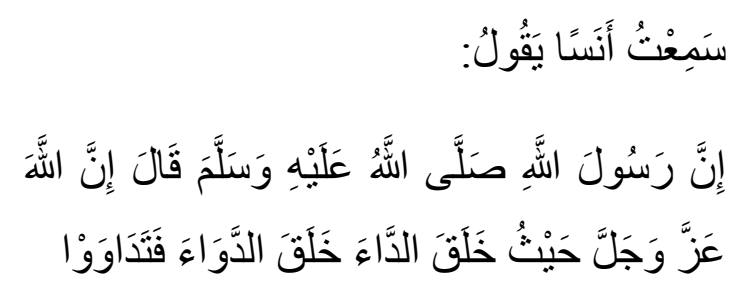

إِنَّ رَسُولَ اللَّهِ صَلَّى اللَّهُ عَلَيْهِهِ وَسَلَّمَ قَالَ إِنَّ اللَّهَ

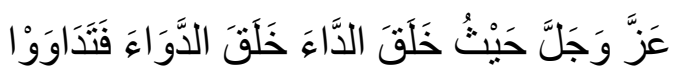


Alya Tursina, Terapi Transplantasi Sel Punca Sebagai Upaya Pelayanan Kesehatan Di Indonesia Dalam...

"Sesungguhnya Allah Azza Wa Jalla setiap kali menciptakan penyakit, Dia menciptakan pula obatnya. Maka berobatlah kalian". ${ }^{9}$

Menteri Agama RI, Suryadharma Ali menegaskan bahwa fatwa dapat menjadikan Islam shalihun li kulli zaman wa makan (sesuai dengan perkembangan situasi dan kondisi zaman). "Fatwa merupakan khazanah intelektual Islam yang sangat khas dan berfungsi secara baik hingga sekarang. Terkait beberapa fenomena perubahan sosial yang terjadi dan membutuhkan fatwa untuk memberikan kepastian hukumnya, fatwa akan selalu hadir tepat waktu dengan substansi yang sesuai kebutuhan masyarakat Muslim.",10

Menurut Maskun, meskipun fiqh merupakan produk pemikiran manusia, tetapi ia dikategorikan sebagai syari'ah sepanjang dikaji dengan merujuk kepada Al-Qur'an dan As-Sunnah baik melalui qiyas maupun maslahah. Seorang mujtahid dengan qiyas membawa furu' kepada nash, sementara dengan maslahah ia berusaha memperhatikan kepentingan-

9 Maslani dan Hasbiyallah, Masail Fiqhiyyah Al-Haditsah: Fiqih Kontemporer, Sega Arsy, Bandung, 2010, hlm. 174.

${ }^{10}$ Suryadharma Ali, loc cit kepentingan kehidupan manusia. ${ }^{11}$ Maslahah dalam kehidupan manusia terwujud dalam dua bentuk yaitu pertama mewujudkan manfaat, kebaikan dan kesenangan untuk manusia dan yang kedua menghindari ummat manusia dari kerusakan dan keburukan. Adapun yang dijadikan tolok ukur untuk menentukan baik buruknya manfaat dan mafsadatnya sesuatu itu dilakukan dalam hal ini terapi transplantasi sel punca disesuaikan dengan apa yang menjadi kebutuhan dasar bagi kehidupan manusia.

Kemajuan ilmu pengetahuan dan teknologi seperti ini menimbulkan dampak tehadap nilai-nilai etik/moral, agama, hukum, sosial, budaya dan aspek lainnya. Aturan hukum mengenai terapi sel punca berbeda-beda di tiap negara dan seringkali berubah seiring dengan perubahan norma-norma budaya maupun ketersediaan perawatan atau tindakan medis. Oleh karena sensitifnya isu ini, pembatasan dan prosedur yang jelas harus dapat selalu diterapkan tanpa memandang status hukumnya. Masalah yang berkaitan dengan terapi sel punca ini akan terus menjadi suatu perdebatan. Bilamana dilihat dari segi perundangundangan memang belum adanya 
Alya Tursina, Terapi Transplantasi Sel Punca Sebagai Upaya Pelayanan Kesehatan Di Indonesia Dalam...

pengaturan yang jelas dan lengkap mengenai penerapan terapi sel punca dan hukum Islam sendiri sehingga penulis ingin melakukan penelitian dengan judul

"Terapi Transplantasi Sel Punca sebagai Upaya Pelayanan Kesehatan di Indonesia dalam Perspektif Hukum Kesehatan dan Hukum Islam”.

\section{B. PEMBAHASAN}

\section{Ketentuan hukum kesehatan dalam} terapi transplantasi sel punca sebagai upaya pelayanan kesehatan di Indonesia.

Di dalam UUD 1945 Pasal 28 H ayat (1) secara jelas dinyatakan bahwa setiap orang berhak hidup sejahtera lahir dan batin, bertempat tinggal, dan mendapatkan lingkungan hidup yang baik dan sehat serta berhak memperoleh pelayanan kesehatan

Berdasarkan Undang-Undang RI No. 36 tahun 2009 Tentang Kesehatan dinyatakan bahwa :

\section{Pasal 66}

Transplantasi sel, baik yang berasal dari manusia maupun dari hewan, hanya dapat dilakukan apabila telah terbukti keamanan dan kemanfaatannya.

\section{Pasal 67}

1. Pengambilan dan pengiriman spesimen atau bagian organ tubuh hanya dapat dilakukan oleh tenaga kesehatan yang mempunyai keahlian dan kewenangan serta dilakukan di fasilitas pelayanan kesehatan tertentu.

2. Ketentuan mengenai syarat dan tata cara pengambilan dan pengiriman spesimen atau bagian organ tubuh sebagaimana dimaksud pada ayat (1) dilaksanakan sesuai dengan ketentuan peraturan perundangundangan.

\section{Pasal 70}

1. Penggunaan sel punca hanya dapat dilakukan untuk tujuan penyembuhan penyakit dan pemulihan kesehatan, serta dilarang digunakan untuk tujuan reproduksi.

2. Sel punca sebagaimana dimaksud pada ayat (1) tidak boleh berasal dari sel punca embrionik.

3. Ketentuan lebih lanjut mengenai penggunaan sel punca sebagaimana dimaksud pada ayat (1) dan ayat (2) diatur dengan Peraturan Menteri. 
Alya Tursina, Terapi Transplantasi Sel Punca Sebagai Upaya Pelayanan Kesehatan Di Indonesia Dalam...

Sel punca embrionik (Embryonic Transplantasi sel punca) mempunyai sifat sebagai berikut

1. Pluripoten, artinya sel punca ini mempunyai kemampuan berdifferensiasi menjadi sel-sel yang merupakan turunan dari 3 lapis germinal, tetapi tidak dapat membentuk membran embrio (tali pusat dan plasenta)

2. Immortal artinya dapat berumur panjang sehingga dapat memperbanyak diri ratusan kali pada media kultur. Mereka merupakan sumber sel-sel yang belum berdifferensiasi. Sel punca embrionik dulu dipikirkan dapat memperbanyak diri sendiri secara tak terbatas, tetapi kini diketahui bahwa usia dan perbanyakan diri sendiri sel-sel stem juga ada batasnya. Hal ini disebabkan karena terjadinya mutasi pada gen-gen pada sel stem yang diakibatkan karena pengaruh nutrisi dalam medium kultur.

3. Mempunyai karyotipe yang normal

4. Dapat bersifat tumorigenik artinya setiap kontaminasi dengan sel yang tak berdifferensiasi dapat menimbulkan kanker

Human Embryonic Transplantasi Stem Cell (hESC) project merupakan penelitian yang ditujukan untuk melakukan duplikasi sel blastokista sehingga dapat digunakan dalam pengobatan sel (therapeutic cloning). Sumber embryo pada penelitian ini biasanya adalah embryo sisa prosedur fertilisasi in vitro pada proses reproduksi buatan (bayi tabung).

Berdasarkan Peraturan Menteri Kesehatan Republik Indoneia Nomor 833/MENKES/PER/IX/2009 tentang Penyelenggaraan Pelayanan Sel Punca di Indonesia adalah sebagai berikut :

Sumber sel punca yang dipergunakan untuk kepentingan pelayanan kesehatan adalah sel punca non embrionik yang berasal dari donor manusia, dan dilarang untuk diperjualbelikan. Donor sel punca adalah bersifat sukarela tanpa pamrih

Sel punca hanya dapat dipergunakan untuk kepentingan pelayanan medik bagi donor itu sendiri atau orang lain atau untuk kepentingan penelitian dan pengembangan ilmu pengetahuan dengan mendapat persetujuan dari donor yang bersangkutan.

Setiap pengambilan sel punca dari donor terlebih dahulu harus mendapatkan persetujuan tertulis dari donor dan dilaksanakan sesuai ketentuan perundangundangan dan hanya dapat dilakukan oleh Rumah Sakit Pendidikan yang telah memiliki kemampuan dan persyaratan dalam pelayanan medik sel punca yang sudah ditunjuk oleh pemerintah. 
Alya Tursina, Terapi Transplantasi Sel Punca Sebagai Upaya Pelayanan Kesehatan Di Indonesia Dalam...

Pengambilan sel punca hanya dapat dilakukan oleh tenaga medis yang mempunyai keahlian dan kompetensi serta dilaksnakan sesuai standar profesi dan standar operasional prosedur yang ditetapkan serta dengan memperhatikan keselamatan donor dan etika profesi.

Sel punca yang diambil dari donor dapat disimpan pada Bank Sel Punca Rumah Sakit atau pada Bank Sel Punca diluar Rumah Sakit yang sudah mendapat izin dari Menteri Kesehatan dengan perjanjian tertulis.

Dalam rangka menjamin mutu pelayanan sel punca pada setiap fasilitas pelayanan kesehatan dilakukan audit secara berkala minimal 2 kali setahun oleh Komite Nasional Sel Punca.

Setiap fasilitas pelayanan medis sel punca harus melakukan pencatatan dan pelaporan semua kegiatan yang berhubungan dengan donasi, pengambilan, pengelolaan, penyimpanan, pendistribusian dan pemberian sel punca dalam penyelenggaraan pelayanan sel punca.

Pembinaan dan pengawasan pealyanan medis sel punca dilakukan oleh Menteri, Dinas Kesehatan Provinsi, Dinas Kesehatan Kabupaten/Kota dan Organisasi Profesi terkait sesuai tugas, fungsi dan tanggung jawabnya masing-masing dibantu oleh Komite Nasional Sel Punca.
Sanksi administratif dapat diambil oleh Menteri terhadap tenaga kesehatan dan atau fasilitas kesehatan yang melakukan pelanggaran terhadap ketentuan perundangundangan yang berlaku dengan cara teguran lisan, teguran tertulis sampai dengan pencabutan izin praktek dan atau izin fasilitas penyelenggaraan pelayanan sel punca.

Perundang-undangan yang terkait dengan pelayanan terapi transplantasi sel punca adalah:

1. Pembukaan Undang-Undang Dasar 1945

2. Undang-Undang Dasar 1945 Pasal $28 \mathrm{H}$ ayat (1) dan Pasal 34 ayat (3 dan 4)

3. Undang-Undang No 8 tahun 1999 tentang Perlindungan Konsumen

4. Undang-Undang No. 18 th 2002 tentang Sistem Nasional Penelitian, Pengembangan, Penerapan Iptek

5. Undang-Undang Kesehatan No. 36 th 2009 tentang Kesehatan

6. Undang- Undang No 29 tahun 2004 tentang Praktik Kedokteran

7. Keputusan Menteri Kesehatan

- Keputusan Menteri Kesehatan Republik Indonesia Nomor 1333/Menkes/SK/XII/1999 tentang Standar Pelayanan Rumah Sakit. 
Alya Tursina, Terapi Transplantasi Sel Punca Sebagai Upaya Pelayanan Kesehatan Di Indonesia Dalam...

- Keputusan Menteri Kesehatan Republik Indonesia Nomor

159/Menkes/SK/II/2009 tentang Penunjukkan RSUP Nasional DR. Ciptomangunkusumo Jakarta sebagai Pusat Penelitian, Pengembangan dan Pelayanan Medis Sel Punca.

- Keputusan Menteri Kesehatan Republik Indonesia Nomor 834/Menkes/SK/IX/2009 tentang Pedoman Pelayanan Medis Sel Punca.

- Keputusan Menteri Kesehatan Republik Indonesia Nomor 604/Menkes/SK/V/2010 tentang Komite Nasional Sel Punca.

\section{Peraturan Menteri Kesehatan}

- Peraturan Menteri Kesehatan Republik Indonesia Nomor 920/MENKES/PER/XII/1986 tentang Upaya Pelayanan Kesehatan Swasta di Bidang Medik.

- Peraturan Menteri Kesehatan Republik Indonesia Nomor 269/MENKES/PER/III/2008 tentang rekam medis.

- Peraturan Menteri Kesehatan Republik Indonesia Nomor 290/MENKES/PER/II/2008 tentang persetujuan tindakan kedokteran.
- Peraturan Menteri Kesehatan Republik Indonesia Nomor 833/MENKES/PER/IX/2009 tentang penyelenggaraan pelayanan sel punca.

- Peraturan Menteri Kesehatan Republik Indonesia Nomor 48 tahun 2012 tentang penyelenggaraan bank sel punca darah tali pusat.

- Peraturan Menteri Kesehatan Republik Indonesia Nomor 50 tahun 2012 tentang penyelenggaraan laboratorium pengolahan sel punca untuk aplikasi klinis.

- Peraturan Menteri Kesehatan Republik Indonesia Nomor 62 tahun 2013 tentang penyelenggaraan bank jaringan dan atau sel.

\section{Ketentuan hukum Islam dalam terapi transplantasi sel punca sebagai upaya pelayanan kesehatan di Indonesia.}

Menurut Jumhurul Ulama bahwa maslahah mursalah dapat sebagai sumber legislasi hukum Islam bila memenuhi syarat sebagai berikut:

a. Maslahah tersebut haruslah "maslahah yang haqiqi" bukan hanya yang berdasarkan prasangka merupakan kemaslahatan yang nyata. Artinya bahwa membina hukum 
Alya Tursina, Terapi Transplantasi Sel Punca Sebagai Upaya Pelayanan Kesehatan Di Indonesia Dalam...

berdasarkan kemaslahatan yang benar-benar dapat membawa kemanfaatan dan menolak kemazdaratan. Akan tetapi kalau hanya sekedar prasangka adanya kemanfaatan atau prasangka adanya penolakan terhadap kemazdaratan, maka pembinaan hukum semacam itu adalah berdasarkan wahm (prasangka) saja dan tidak berdasarkan syari'at yang benar.

b. Kemaslahatan tersebut merupakan kemaslahatan yang umum, bukan kemaslahatan yang khusus baik untuk perseorangan atau kelompok tertentu, dikarenakan kemaslahatan tersebut harus bisa dimanfaatkan oleh orang banyak dan dapat menolak kemudaratan terhadap orang banyak pula.

c. Kemaslahatan tersebut tidak bertentangan dengan kemaslahatan yang terdapat dalm al-Qur'an dan alHadits baik secara zdahir atau batin. Oleh karena itu tidak dianggap suatu kemaslahatan yang kontradiktif dengan nash seperti menyamakan bagian anak laki-laki dengan perempuan dalam pembagian waris, walau penyamaan pembagian tersebut berdalil kesamaan dalam pembagian. $^{12}$

Dari ketentuan di atas dapat dirumuskan bahwa maslahah mursalah dapat dijadikan sebagai landasan hukum serta dapat diaplikasikan dalam tindakan sehari-hari bila telah memenuhi syarat sebagai tersebut di atas, dan ditambahkan maslahah tersebut merupakan kemaslahatan yang nyata, tidak sebatas kemaslahatan yang sifatnya masih prasangka, yang sekiranya dapat menarik suatu kemanfaatan dan menolak kemudaratan. Dan maslahah tersebut mengandung kemanfa'atan secara umum dengan mempunyai akses secara menyeluruh dan tidak melenceng dari tujuan-tujuan yang dikandung dalam al-Qur'an dan al-Hadits. ${ }^{13}$

Pada beberapa agama, embrio manusia adalah wujud manusia dalam wujud konsepsi, sementara bagi agama lainnya yang penting adalah saat penjiwaan, yaitu embrio berkembang dan memperoleh jiwa. Negara Islam juga telah terlibat dalam riset sel punca, di antaranya adalah Iran yang memulai pada 2003. Di negara-negara mayoritas Muslim, riset embrio dipengaruhi dari

\footnotetext{
${ }^{12}$ Mukhsin Jamil (ed.), Kemaslahatan dan Pembaharuan Hukum Islam, Walisongo Press, Semarang, 2008, hlm. 24.

${ }^{13}$ Ibid
} 
Alya Tursina, Terapi Transplantasi Sel Punca Sebagai Upaya Pelayanan Kesehatan Di Indonesia Dalam...

kepercayaan agama bahwa hidup manusia dimulai hanya setelah peniupan ruh ke dalam janin; sekitar 120 hari setelah penciptaan. Islamic Law Council of North America menyatakan bahwa embrio yang digunakan untuk riset sel punca setelah di luar tubuh maka tidak mungkin menjadi manusia. Kontroversi dalam dunia Muslim adalah menciptakan embrio untuk tujuan riset.

Para ulama yang mendukung pembolehan transplantasi sel punca berpendapat bahwa transplantasi tersebut harus dipahami sebagai satu bentuk layanan altruistik bagi sesama muslim. Pendirian mereka tentang transplantasi organ dan sel punca dapat diringkas sebagai berikut:

\section{a. Kesejahteraan publik (al-Mashlahah)}

Kebolehan transplantasi organ harus dibatasi dengan ketentuan-ketentuan berikut:

- Transplantasi sel punca tersebut merupakan pengobatan terbaik yang bisa ditempuh.

- Derajat keberhasilan dari prosedur ini diperkirakan tinggi.

- Ada persetujuan dari donor sel punca yang akan ditransplantasikan atau dari ahli warisnya.

- Dokter yang melakukannya merupakan tenaga ahli yang kompeten di bidang tersebut.
- Resipien organ tersebut sudah diberitahu tentang operasi transplantasi berikut implikasinya.

b. Altruisme (al-Itsar)

Dalam surat Al-Maidah ayat 2 telah menganjurkan bahwa umat Islam untuk bekerja sama satu sama lain dan memperkuat ikatan persaudaraan mereka. Dengan demikian, berdasarkan ajaran diatas, tindakan seseorang yang masih hidup untuk menjadi donor transplantasi sel punca baik untuk dirinya apalagi untuk orang lain yang sangat membutuhkan harus dipandang sebagai tindakan altruisme dari orang-orang yang menyadari bahwa mereka memiliki sesuatu yang bermanfaat bagi orang lain. ${ }^{14}$

Berdasarkan hasil wawancara peneliti dengan Miftah Farid sebagai Ketua Majelis Ulama Indonesia Jawa Barat, pendapat beliau mengenai terapi transplantasi sel punca secara garis besarnya adalah sebagai berikut :

a. Berobat adalah wajib hukumnya

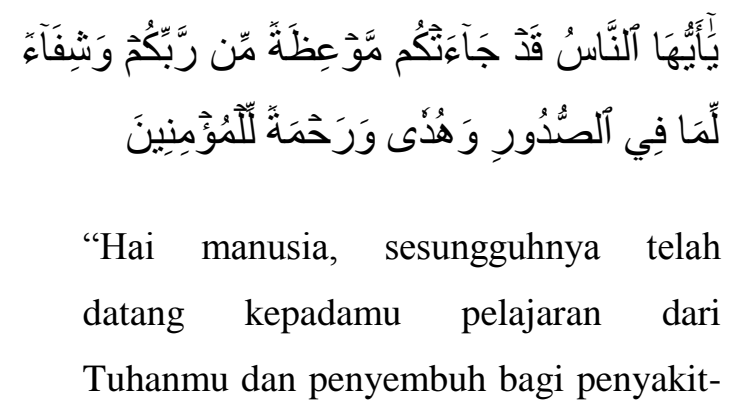

${ }^{14}$ Mahjuddin. "MASAILUL FIQHIYAH berbagai kasus yang dihadapi 'hukum islam' masa kini”. Jakarta, Kalam Mulia. 2003. hlm. 122 
Alya Tursina, Terapi Transplantasi Sel Punca Sebagai Upaya Pelayanan Kesehatan Di Indonesia Dalam...

penyakit (yang berada) dalam dada dan petunjuk serta rahmat bagi orang-orang yang beriman." (QS:Yunus 57). ${ }^{15}$

Rasulullah Saw bersabda:

"Sesungguhnya Allah telah menurunkan penyakit dan obatnya, demikian pula Allah menjadikan bagi setiap penyakit ada obatnya. Maka berobatlah kalian dan janganlah berobat dengan yang haram.” (HR. Abu Dawud dari Abud Darda` radhiallahu 'anhu)

Imam Ahmad telah meriwayatkan hadits dari Anas Ra yang telah berkata, bahwa Rasulullah Saw bersabda:

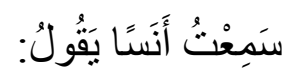

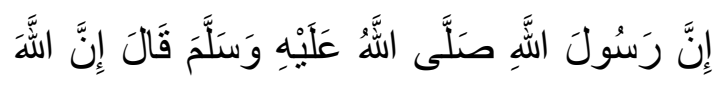

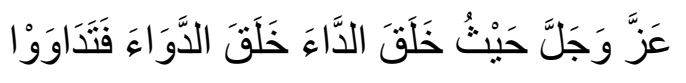

"Sesungguhnya Allah Azza Wa Jalla setiap kali menciptakan penyakit, Dia menciptakan pula obatnya. Maka berobatlah kalian". ${ }^{16}$

15 Departemen Agama RI, Al Qur'an Dan Terjemahannya, Op. cit.

${ }_{16}$ Maslani dan Hasbiyallah, Masail Fiqhiyyah Al-Haditsah: Fiqih Kontemporer, Sega Arsy, Bandung, 2010, hlm. 174
Terapi transplantasi sel punca merupakan penyembuhan yang terbaik bila tidak ada alternatif lain dengan risiko yang lebih rendah bagi penyakit tersebut. AlQuran menyebutkan bahwa Islam tidak membenarkan seseorang membiarkan dirinya dalam bahaya, tanpa berusaha mencari penyembuhan secara medis dan non medis, termasuk upaya transplantasi, yang memberi harapan untuk bisa bertahan hidup dan menjadi sehat kembali. Al-Quran surah AlBaqarah ayat 195 menyebutkan bahwa Islam tidak membenarkan seseorang membiarkan dirinya dalam bahaya, tanpa berusaha mencari penyembuhan secara medis dan non medis, termasuk upaya transplantasi, yang memberi harapan untuk bisa bertahan hidup dan menjadi sehat kembali.

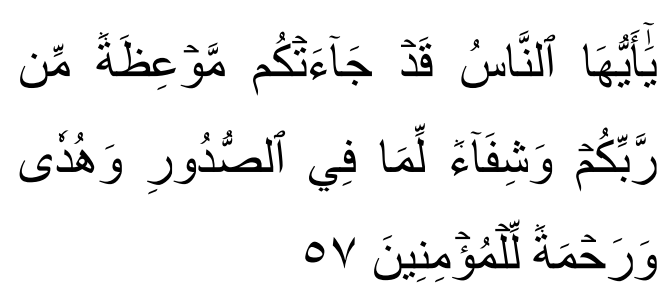

"Hai manusia, sesungguhnya telah datang kepadamu pelajaran dari Tuhanmu dan penyembuh bagi penyakitpenyakit (yang berada) dalam dada dan petunjuk serta rahmat bagi orang-orang yang beriman" (QS Yunus : 59) 


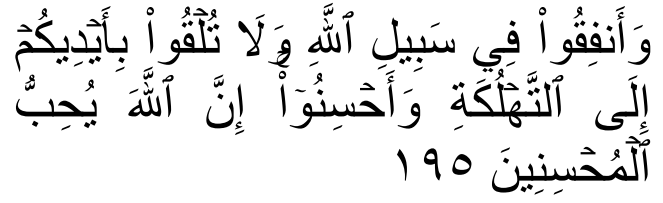

"Dan belanjakanlah (harta bendamu) di jalan Allah, dan janganlah kamu menjatuhkan dirimu sendiri ke dalam kebinasaan, dan berbuat baiklah, karena sesungguhnya Allah menyukai orang-orang yang berbuat baik" (QS Al Baqarah : 195)

مَأَ......

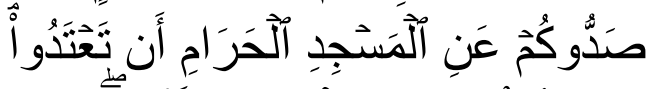

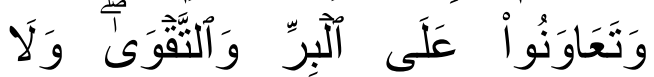

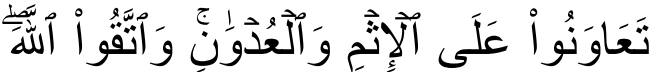

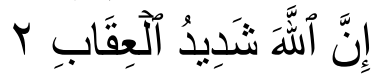

“...... Dan tolong-menolonglah kamu dalam (mengerjakan) kebajikan dan takwa, dan jangan tolong-menolong dalam berbuat dosa dan pelanggaran. Dan bertakwalah kamu kepada Allah, sesungguhnya Allah amat berat siksaNya" (QS. Al Maidah : 2)

Dalam hadits lain, Rasulullah bersabda pula : "Setiap penyakit ada obatnya, apabila obat itu tepat, maka penyakit itu akan sembuh atas izin Allah". (HR. Ahmad dan Muslim dari Jabir). b. Selanjutnya, bertalian dengan transplantasi dengan organ tubuh hewan diharamkan yang dicangkokkan kepada manusia, seperti katup jantung babi atau ginjalnya, dalam hal ini haram hukumnya, dengan dasar qaidah fiqh :

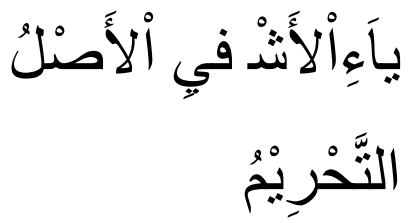

"Pada dasarnya segala sesuatu itu adalah haram".

c. Hukum transplantasi atau cangkok organ tubuh diperbolehkan selama sesuai dengan ketentuan syariat, diantaranya tidak berasal dari embrio manusia dan tidak untuk diperjualbelikan.

Berdasarkan pembahasan pada bab-bab terdahulu, maka pada bab ini akan dikemukakan beberapa simpulan, sebagai berikut :

a. Pelayanan medik terapi transplantasi sel punca di Indonesia sudah memadai dimulai dari falsafah, konsep sampai pedoman penyelenggaraan terapi transplantasi sel punca. 
Alya Tursina, Terapi Transplantasi Sel Punca Sebagai Upaya Pelayanan Kesehatan Di Indonesia Dalam...

Pelaksanaan pelayanan kesehatan terapi transplantasi sel punca di Indonesia saat ini dipayungi oleh Undang-Undang RI No. 36 tahun 2009 Tentang Kesehatan Pasal 66,67 dan Pasal 70 dan Peraturan Menteri Kesehatan Republik Indonesia Nomor 833/MENKES/PER/IX/2009 tentang penyelenggaraan pelayanan sel punca dan Keputusan Menteri Kesehatan Republik Indonesia Nomor 834/Menkes/SK/IX/2009 tentang Pedoman Pelayanan Medis Sel Punca.

b. Pelaksanaan terapi transplantasi sel punca menurut hukum Islam pada dasarnya harus dapat memelihara kepentingan hidup dengan menjaga dan memelihara kemashlahatan manusia, meskipun belum ada fatwa yang mendetail mengenai transplantasi sel punca dengan merujuk kepada ijtihad menggunakan metode penalaran hukum Islam pola istishlahi membolehkan terapi transplantasi sel punca. Kedua hukum ini mempunyai batasan mengenai tansplantasi sel punca dan sepakat bahwa terapi transplantasi menggunakan sel punca non embrionik dapat dilakukan di Indonesia sepanjang memenuhi standar/pedoman dan berbagai pengaturan/perundangan yang ada di Indonesia sedangkan sel punca embrionik pluripotent dan totipotent dilarang karena menganggu martabat manusia.

1. Mengingat penggunaan sel punca embrionik Human Embryonic Stem Cell (hESC) project masih dipergunakan sebagai penelitian yang ditujukan untuk pengobatan sel (therapeutic cloning) dengan sumber embryo sisa prosedur fertilisasi in vitro pada proses reproduksi buatan (bayi tabung) belum ada ketentuan yang tegas untuk ini. Sehingga peraturan perundang-undangan seyogyanya lebih komprehensif agar terapi ini tidak disalahgunakan dan sesuai dengan pedoman perundang-undangan yang berlaku di Indonesia.

2. Perkembangan ilmu pengetahuan dan teknologi yang begitu pesat ini seyogyanya diantisipasi 
Alya Tursina, Terapi Transplantasi Sel Punca Sebagai Upaya Pelayanan Kesehatan Di Indonesia Dalam...

dengan cepat oleh para ulama dan cendekiawan muslim sehingga fatwa yang keluar dari Majelis Ulama Indonesia bisa menjadi pegangan bagi para dokter muslim dan masyarakat dalam penyelenggaraan pelayanan terapi transplantasi sel punca.

\section{Ketentuan hukum kesehatan dalam} terapi transplantasi sel punca sebagai upaya pelayanan kesehatan di Indonesia.

Di dalam UUD 1945 Pasal 28 H ayat (1) secara jelas dinyatakan bahwa setiap orang berhak hidup sejahtera lahir dan batin, bertempat tinggal, dan mendapatkan lingkungan hidup yang baik dan sehat serta berhak memperoleh pelayanan kesehatan

Berdasarkan Undang-Undang RI No. 36 tahun 2009 Tentang Kesehatan dinyatakan bahwa :

\section{Pasal 66}

Transplantasi sel, baik yang berasal dari manusia maupun dari hewan, hanya dapat dilakukan apabila telah terbukti keamanan dan kemanfaatannya.

\section{Pasal 67}

3. Pengambilan dan pengiriman spesimen atau bagian organ tubuh hanya dapat dilakukan oleh tenaga kesehatan yang mempunyai keahlian dan kewenangan serta dilakukan di fasilitas pelayanan kesehatan tertentu.

4. Ketentuan mengenai syarat dan tata cara pengambilan dan pengiriman spesimen atau bagian organ tubuh sebagaimana dimaksud pada ayat (1) dilaksanakan sesuai dengan ketentuan peraturan perundangundangan.

\section{Pasal 70}

4. Penggunaan sel punca hanya dapat dilakukan untuk tujuan penyembuhan penyakit dan pemulihan kesehatan, serta dilarang digunakan untuk tujuan reproduksi.

5. Sel punca sebagaimana dimaksud pada ayat (1) tidak boleh berasal dari sel punca embrionik.

6. Ketentuan lebih lanjut mengenai penggunaan sel punca sebagaimana dimaksud pada ayat (1) dan ayat (2) diatur dengan Peraturan Menteri.

Sel punca embrionik (Embryonic Transplantasi sel punca) mempunyai sifat sebagai berikut 
Alya Tursina, Terapi Transplantasi Sel Punca Sebagai Upaya Pelayanan Kesehatan Di Indonesia Dalam...

5. Pluripoten, artinya sel punca ini mempunyai kemampuan berdifferensiasi menjadi sel-sel yang merupakan turunan dari 3 lapis germinal, tetapi tidak dapat membentuk membran embrio (tali pusat dan plasenta)

6. Immortal artinya dapat berumur panjang sehingga dapat memperbanyak diri ratusan kali pada media kultur. Mereka merupakan sumber sel-sel yang belum berdifferensiasi. Sel punca embrionik dulu dipikirkan dapat memperbanyak diri sendiri secara tak terbatas, tetapi kini diketahui bahwa usia dan perbanyakan diri sendiri sel-sel stem juga ada batasnya. Hal ini disebabkan karena terjadinya mutasi pada gen-gen pada sel stem yang diakibatkan karena pengaruh nutrisi dalam medium kultur.

7. Mempunyai karyotipe yang normal

8. Dapat bersifat tumorigenik artinya setiap kontaminasi dengan sel yang tak berdifferensiasi dapat menimbulkan kanker

\section{Human Embryonic Transplantasi}

Stem Cell (hESC) project merupakan penelitian yang ditujukan untuk melakukan duplikasi sel blastokista sehingga dapat digunakan dalam pengobatan sel (therapeutic cloning). Sumber embryo pada penelitian ini biasanya adalah embryo sisa prosedur fertilisasi in vitro pada proses reproduksi buatan (bayi tabung).

\section{Berdasarkan Peraturan Menteri}

Kesehatan Republik Indoneia Nomor 833/MENKES/PER/IX/2009 tentang Penyelenggaraan Pelayanan Sel Punca di Indonesia adalah sebagai berikut :

Sumber sel punca yang dipergunakan untuk kepentingan pelayanan kesehatan adalah sel punca non embrionik yang berasal dari donor manusia, dan dilarang untuk diperjualbelikan. Donor sel punca adalah bersifat sukarela tanpa pamrih

Sel punca hanya dapat dipergunakan untuk kepentingan pelayanan medik bagi donor itu sendiri atau orang lain atau untuk kepentingan penelitian dan pengembangan ilmu pengetahuan dengan mendapat persetujuan dari donor yang bersangkutan.

Setiap pengambilan sel punca dari donor terlebih dahulu harus mendapatkan persetujuan tertulis dari donor dan dilaksanakan sesuai ketentuan perundangundangan dan hanya dapat dilakukan oleh Rumah Sakit Pendidikan yang telah memiliki kemampuan dan persyaratan dalam pelayanan medik sel punca yang sudah ditunjuk oleh pemerintah.

Pengambilan sel punca hanya dapat dilakukan oleh tenaga medis yang mempunyai keahlian dan kompetensi serta 
Alya Tursina, Terapi Transplantasi Sel Punca Sebagai Upaya Pelayanan Kesehatan Di Indonesia Dalam...

dilaksnakan sesuai standar profesi dan standar operasional prosedur yang ditetapkan serta dengan memperhatikan keselamatan donor dan etika profesi.

Sel punca yang diambil dari donor dapat disimpan pada Bank Sel Punca Rumah Sakit atau pada Bank Sel Punca diluar Rumah Sakit yang sudah mendapat izin dari Menteri Kesehatan dengan perjanjian tertulis.

Dalam rangka menjamin mutu pelayanan sel punca pada setiap fasilitas pelayanan kesehatan dilakukan audit secara berkala minimal 2 kali setahun oleh Komite Nasional Sel Punca.

Setiap fasilitas pelayanan medis sel punca harus melakukan pencatatan dan pelaporan semua kegiatan yang berhubungan dengan donasi, pengambilan, pengelolaan, penyimpanan, pendistribusian dan pemberian sel punca dalam penyelenggaraan pelayanan sel punca.

Pembinaan dan pengawasan pealyanan medis sel punca dilakukan oleh Menteri, Dinas Kesehatan Provinsi, Dinas Kesehatan Kabupaten/Kota dan Organisasi Profesi terkait sesuai tugas, fungsi dan tanggung jawabnya masing-masing dibantu oleh Komite Nasional Sel Punca.

Sanksi administratif dapat diambil oleh Menteri terhadap tenaga kesehatan dan atau fasilitas kesehatan yang melakukan pelanggaran terhadap ketentuan perundangundangan yang berlaku dengan cara teguran lisan, teguran tertulis sampai dengan pencabutan izin praktek dan atau izin fasilitas penyelenggaraan pelayanan sel punca.

Perundang-undangan yang terkait dengan pelayanan terapi transplantasi sel punca adalah:

9. Pembukaan Undang-Undang Dasar 1945

10. Undang-Undang Dasar 1945 Pasal $28 \mathrm{H}$ ayat (1) dan Pasal 34 ayat (3 dan 4)

11. Undang-Undang No 8 tahun 1999 tentang Perlindungan Konsumen

12. Undang-Undang No. 18 th 2002 tentang Sistem Nasional Penelitian, Pengembangan, Penerapan Iptek

13. Undang-Undang Kesehatan No. 36 th 2009 tentang Kesehatan

14. Undang- Undang No 29 tahun 2004 tentang Praktik Kedokteran

15. Keputusan Menteri Kesehatan

- Keputusan Menteri Kesehatan Republik Indonesia Nomor 1333/Menkes/SK/XII/1999 tentang Standar Pelayanan Rumah Sakit.

- Keputusan Menteri Kesehatan Republik Indonesia Nomor 159/Menkes/SK/II/2009 tentang Penunjukkan RSUP Nasional DR. 
Alya Tursina, Terapi Transplantasi Sel Punca Sebagai Upaya Pelayanan Kesehatan Di Indonesia Dalam...

Ciptomangunkusumo Jakarta sebagai

Pusat Penelitian, Pengembangan dan Pelayanan Medis Sel Punca.

- Keputusan Menteri Kesehatan Republik Indonesia Nomor 834/Menkes/SK/IX/2009 tentang Pedoman Pelayanan Medis Sel Punca.

- Keputusan Menteri Kesehatan Republik Indonesia Nomor 604/Menkes/SK/V/2010 tentang Komite Nasional Sel Punca.

\section{Peraturan Menteri Kesehatan}

- Peraturan Menteri Kesehatan Republik Indonesia Nomor 920/MENKES/PER/XII/1986

tentang Upaya Pelayanan Kesehatan Swasta di Bidang Medik.

- Peraturan Menteri Kesehatan Republik Indonesia Nomor 269/MENKES/PER/III/2008 tentang rekam medis.

- Peraturan Menteri Kesehatan Republik Indonesia Nomor 290/MENKES/PER/II/2008 tentang persetujuan tindakan kedokteran.

- Peraturan Menteri Kesehatan Republik Indonesia Nomor 833/MENKES/PER/IX/2009 tentang penyelenggaraan pelayanan sel punca.

- Peraturan Menteri Kesehatan Republik Indonesia Nomor 48 tahun
2012 tentang penyelenggaraan bank sel punca darah tali pusat.

- Peraturan Menteri Kesehatan Republik Indonesia Nomor 50 tahun 2012 tentang penyelenggaraan laboratorium pengolahan sel punca untuk aplikasi klinis.

- Peraturan Menteri Kesehatan Republik Indonesia Nomor 62 tahun 2013 tentang penyelenggaraan bank jaringan dan atau sel.

\section{Ketentuan hukum Islam dalam terapi transplantasi sel punca sebagai upaya pelayanan kesehatan di Indonesia.}

Menurut Jumhurul Ulama bahwa maslahah mursalah dapat sebagai sumber legislasi hukum Islam bila memenuhi syarat sebagai berikut:

d. Maslahah tersebut haruslah "maslahah yang haqiqi" bukan hanya yang berdasarkan prasangka merupakan kemaslahatan yang nyata. Artinya bahwa membina hukum berdasarkan kemaslahatan yang benar-benar dapat membawa kemanfaatan dan menolak kemazdaratan. Akan tetapi kalau hanya sekedar prasangka adanya kemanfaatan atau prasangka adanya 
Alya Tursina, Terapi Transplantasi Sel Punca Sebagai Upaya Pelayanan Kesehatan Di Indonesia Dalam...

penolakan terhadap kemazdaratan, maka pembinaan hukum semacam itu adalah berdasarkan wahm (prasangka) saja dan tidak berdasarkan syari'at yang benar.

e. Kemaslahatan tersebut merupakan kemaslahatan yang umum, bukan kemaslahatan yang khusus baik untuk perseorangan atau kelompok tertentu, dikarenakan kemaslahatan tersebut harus bisa dimanfaatkan oleh orang banyak dan dapat menolak kemudaratan terhadap orang banyak pula.

f. Kemaslahatan tersebut tidak bertentangan dengan kemaslahatan yang terdapat dalm al-Qur'an dan alHadits baik secara zdahir atau batin. Oleh karena itu tidak dianggap suatu kemaslahatan yang kontradiktif dengan nash seperti menyamakan bagian anak laki-laki dengan perempuan dalam pembagian waris, walau penyamaan pembagian tersebut berdalil kesamaan dalam pembagian. $^{17}$

Dari ketentuan di atas dapat dirumuskan bahwa maslahah mursalah dapat

\footnotetext{
${ }^{17}$ Mukhsin Jamil (ed.), Kemaslahatan dan Pembaharuan Hukum Islam, Walisongo Press, Semarang, 2008, hlm. 24.
}

dijadikan sebagai landasan hukum serta dapat diaplikasikan dalam tindakan sehari-hari bila telah memenuhi syarat sebagai tersebut di atas, dan ditambahkan maslahah tersebut merupakan kemaslahatan yang nyata, tidak sebatas kemaslahatan yang sifatnya masih prasangka, yang sekiranya dapat menarik suatu kemanfaatan dan menolak kemudaratan. Dan maslahah tersebut mengandung kemanfa'atan secara umum dengan mempunyai akses secara menyeluruh dan tidak melenceng dari tujuan-tujuan yang dikandung dalam al-Qur'an dan al-Hadits. ${ }^{18}$

Pada beberapa agama, embrio manusia adalah wujud manusia dalam wujud konsepsi, sementara bagi agama lainnya yang penting adalah saat penjiwaan, yaitu embrio berkembang dan memperoleh jiwa. Negara Islam juga telah terlibat dalam riset sel punca, di antaranya adalah Iran yang memulai pada 2003. Di negara-negara mayoritas Muslim, riset embrio dipengaruhi dari kepercayaan agama bahwa hidup manusia dimulai hanya setelah peniupan ruh ke dalam janin; sekitar 120 hari setelah penciptaan. Islamic Law Council of North America menyatakan bahwa embrio yang digunakan untuk riset sel punca setelah di luar tubuh maka tidak

$$
{ }^{18} \text { Ibid }
$$


Alya Tursina, Terapi Transplantasi Sel Punca Sebagai Upaya Pelayanan Kesehatan Di Indonesia Dalam...

mungkin menjadi manusia. Kontroversi dalam dunia Muslim adalah menciptakan embrio untuk tujuan riset.

Para ulama yang mendukung pembolehan transplantasi sel punca berpendapat bahwa transplantasi tersebut harus dipahami sebagai satu bentuk layanan altruistik bagi sesama muslim. Pendirian mereka tentang transplantasi organ dan sel punca dapat diringkas sebagai berikut:

\section{b. Kesejahteraan publik (al-Mashlahah)}

Kebolehan transplantasi organ harus dibatasi dengan ketentuan-ketentuan berikut:

- Transplantasi sel punca tersebut merupakan pengobatan terbaik yang bisa ditempuh.

- Derajat keberhasilan dari prosedur ini diperkirakan tinggi.

- Ada persetujuan dari donor sel punca yang akan ditransplantasikan atau dari ahli warisnya.

- Dokter yang melakukannya merupakan tenaga ahli yang kompeten di bidang tersebut.

- Resipien organ tersebut sudah diberitahu tentang operasi transplantasi berikut implikasinya.

c. Altruisme (al-Itsar)

Dalam surat Al-Maidah ayat 2 telah menganjurkan bahwa umat Islam untuk bekerja sama satu sama lain dan memperkuat ikatan persaudaraan mereka. Dengan demikian, berdasarkan ajaran diatas, tindakan seseorang yang masih hidup untuk menjadi donor transplantasi sel punca baik untuk dirinya apalagi untuk orang lain yang sangat membutuhkan harus dipandang sebagai tindakan altruisme dari orang-orang yang menyadari bahwa mereka memiliki sesuatu yang bermanfaat bagi orang lain. ${ }^{19}$

$$
\text { Berdasarkan hasil wawancara }
$$
peneliti dengan Miftah Farid sebagai Ketua Majelis Ulama Indonesia Jawa Barat, pendapat beliau mengenai terapi transplantasi sel punca secara garis besarnya adalah sebagai berikut :

d. Berobat adalah wajib hukumnya

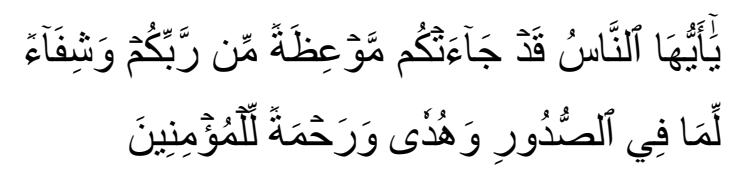

"Hai manusia, sesungguhnya telah datang kepadamu pelajaran dari Tuhanmu dan penyembuh bagi penyakitpenyakit (yang berada) dalam dada dan petunjuk serta rahmat bagi orang-orang yang beriman.” (QS:Yunus 57). ${ }^{20}$

Rasulullah Saw bersabda:

\footnotetext{
${ }^{19}$ Mahjuddin. "MASAILUL FIQHIYAH berbagai kasus yang dihadapi 'hukum islam' masa kini”. Jakarta, Kalam Mulia. 2003. hlm. 122

20 Departemen Agama RI, Al Qur'an Dan Terjemahannya, Op. cit.
} 
Alya Tursina, Terapi Transplantasi Sel Punca Sebagai Upaya Pelayanan Kesehatan Di Indonesia Dalam...

"Sesungguhnya Allah telah menurunkan penyakit dan obatnya, demikian pula Allah menjadikan bagi setiap penyakit ada obatnya. Maka berobatlah kalian dan janganlah berobat dengan yang haram." (HR. Abu Dawud dari Abud Darda' radhiallahu 'anhu)

Imam Ahmad telah meriwayatkan hadits dari Anas Ra yang telah berkata, bahwa Rasulullah Saw bersabda:

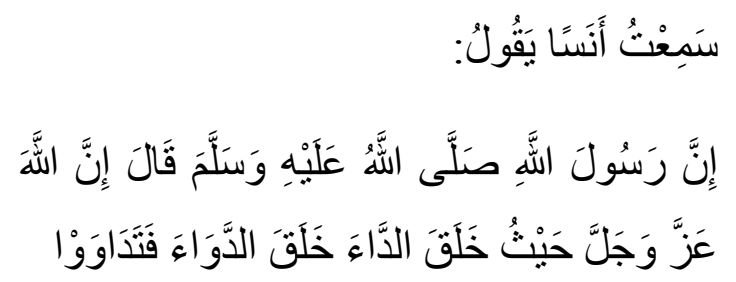

"Sesungguhnya Allah Azza Wa Jalla setiap kali menciptakan penyakit, Dia menciptakan pula obatnya. Maka berobatlah kalian" ${ }^{21}$

Terapi transplantasi sel punca merupakan penyembuhan yang terbaik bila tidak ada alternatif lain dengan risiko yang lebih rendah bagi penyakit tersebut. AlQuran menyebutkan bahwa Islam tidak membenarkan seseorang membiarkan dirinya dalam bahaya, tanpa berusaha mencari penyembuhan secara medis dan non medis,

21 Maslani dan Hasbiyallah, Masail Fiqhiyyah Al-Haditsah: Fiqih Kontemporer, Sega Arsy, Bandung, 2010, hlm. 174 termasuk upaya transplantasi, yang memberi harapan untuk bisa bertahan hidup dan menjadi sehat kembali. Al-Quran surah AlBaqarah ayat 195 menyebutkan bahwa Islam tidak membenarkan seseorang membiarkan dirinya dalam bahaya, tanpa berusaha mencari penyembuhan secara medis dan non medis, termasuk upaya transplantasi, yang memberi harapan untuk bisa bertahan hidup dan menjadi sehat kembali.

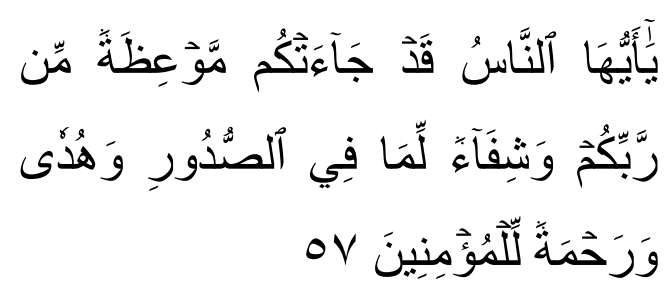

"Hai manusia, sesungguhnya telah datang kepadamu pelajaran dari Tuhanmu dan penyembuh bagi penyakitpenyakit (yang berada) dalam dada dan petunjuk serta rahmat bagi orang-orang yang beriman" (QS Yunus : 59)

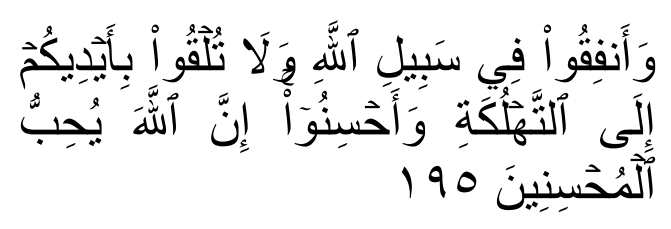

"Dan belanjakanlah (harta bendamu) di jalan Allah, dan janganlah kamu menjatuhkan dirimu sendiri ke dalam kebinasaan, dan berbuat baiklah, karena sesungguhnya Allah 
menyukai orang-orang yang berbuat baik" (QS Al Baqarah : 195)

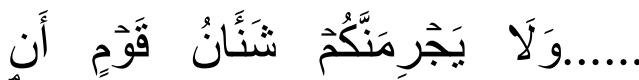

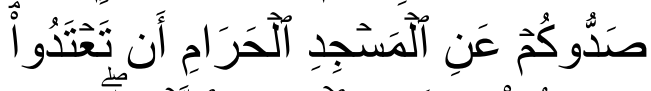

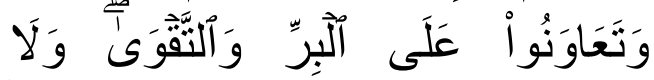

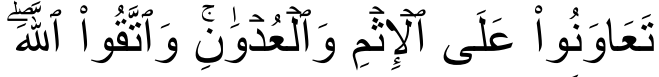

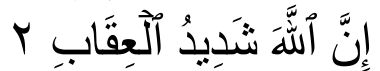

“..... Dan tolong-menolonglah kamu dalam (mengerjakan) kebajikan dan takwa, dan jangan tolong-menolong dalam berbuat dosa dan pelanggaran. Dan bertakwalah kamu kepada Allah, sesungguhnya Allah amat berat siksaNya” (QS. Al Maidah : 2)

Dalam hadits lain, Rasulullah bersabda pula : "Setiap penyakit ada obatnya, apabila obat itu tepat, maka penyakit itu akan sembuh atas izin Allah". (HR. Ahmad dan Muslim dari Jabir).

e. Selanjutnya, bertalian dengan transplantasi dengan organ tubuh hewan diharamkan yang dicangkokkan kepada manusia, seperti katup jantung babi atau ginjalnya, dalam hal ini haram hukumnya, dengan dasar qaidah fiqh :
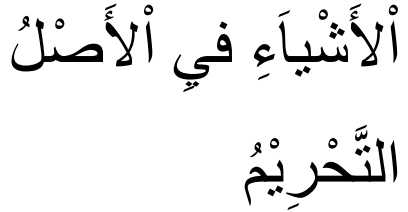

"Pada dasarnya segala sesuatu itu adalah haram".

f. Hukum transplantasi atau cangkok organ tubuh diperbolehkan selama sesuai dengan ketentuan syariat, diantaranya tidak berasal dari embrio manusia dan tidak untuk diperjualbelikan.

\section{Simpulan dan Saran}

\section{Simpulan}

1. Pelayanan medik terapi transplantasi sel punca di Indonesia sudah memadai dimulai dari falsafah, konsep sampai pedoman penyelenggaraan terapi transplantasi sel punca. Pelaksanaan pelayanan kesehatan terapi transplantasi sel punca di Indonesia saat ini dipayungi oleh Undang-Undang RI No. 36 tahun 2009 Tentang Kesehatan Pasal 66,67 dan Pasal 70 dan Peraturan Menteri Kesehatan Republik Indonesia Nomor 833/MENKES/PER/IX/2009 tentang penyelenggaraan 
Alya Tursina, Terapi Transplantasi Sel Punca Sebagai Upaya Pelayanan Kesehatan Di Indonesia Dalam...

pelayanan sel punca dan

Keputusan Menteri Kesehatan

Republik Indonesia Nomor

834/Menkes/SK/IX/2009 tentang

Pedoman Pelayanan Medis Sel Punca.

2. Pelaksanaan terapi transplantasi sel punca menurut hukum Islam pada dasarnya harus dapat memelihara kepentingan hidup dengan menjaga dan memelihara kemashlahatan manusia, meskipun belum ada fatwa yang mendetail mengenai transplantasi sel punca dengan merujuk kepada ijtihad menggunakan metode penalaran hukum Islam pola istishlahi membolehkan terapi transplantasi sel punca. Kedua hukum ini mempunyai batasan mengenai tansplantasi sel punca dan sepakat bahwa terapi transplantasi menggunakan sel punca non embrionik dapat dilakukan di Indonesia sepanjang memenuhi standar/pedoman dan berbagai pengaturan/perundangan yang ada di Indonesia sedangkan sel punca embrionik pluripotent dan totipotent dilarang karena menganggu martabat manusia.

\section{Saran}

1. Mengingat penggunaan sel punca embrionik Human Embryonic Stem Cell (hESC) project masih dipergunakan sebagai penelitian yang ditujukan untuk pengobatan sel (therapeutic cloning) dengan sumber embryo sisa prosedur fertilisasi in vitro pada proses reproduksi buatan (bayi tabung) belum ada ketentuan yang tegas untuk ini. Sehingga peraturan perundang-undangan seyogyanya lebih komprehensif agar terapi ini tidak disalahgunakan dan sesuai dengan pedoman perundangundangan yang berlaku di Indonesia.

2. Perkembangan ilmu pengetahuan dan teknologi yang begitu pesat ini seyogyanya diantisipasi dengan cepat oleh para ulama dan cendekiawan muslim sehingga fatwa yang keluar dari Majelis Ulama Indonesia bisa menjadi pegangan bagi para dokter muslim dan masyarakat dalam penyelenggaraan pelayanan terapi transplantasi sel punca. 
Alya Tursina, Terapi Transplantasi Sel Punca Sebagai Upaya Pelayanan Kesehatan Di Indonesia Dalam...

\section{DAFTAR PUSTAKA}

\section{Buku}

Amin Soebandrio, Pedoman Riset Sel Punca Manusia, Edisi Pertama, Asosiasi sel Punca Indonesia, Jakarta, 2010

Departemen Agama RI, Al Qur'an Dan Terjemahannya, PT Serajaya Santra, Jakarta, 1987

Hermien Hadiati Koeswadji, Beberapa Permasalahan Hukum dan Medik, PT. Citra Aditya Bakti, Cetakan 1, Bandung, 1992

\section{Hukum}

Kedokteran, Studi Tentang Hubungan Hukum Dalam Mana Dokter Sebagai Salah Satu Pihak, PT. Citra Aditya Bakti, Bandung, 1998

Kamus Besar Bahasa Indonesia, Edisi Ke-3, 2005

Mahjuddin. "Masailul Fiqiyah : Berbagai kasus yang dihadapi 'Hukum Islam' masa kini”. Jakarta, Kalam Mulia. 2003 , Masâil Al-Fiqh: Kasus-Kasus Aktual dalam Hukum Islam, Kalam Mulia, Jakarta, 2012

Maslani dan Hasbiyallah, Masail Fiqhiyyah Al-Haditsah: Fiqih Kontemporer, Sega Arsy, Bandung, 2010

Mukhsin Jamil (ed.), Kemaslahatan dan Pembaharuan Hukum Islam, Walisongo Press, Semarang, 2008

Suparman Usman, Hukum Islam Asasasas dan Pengantar Studi Hukum Islam dalam Tata Hukum Indonesia, Gema Media Pratama, Cetakan ke-2, Jakarta, 2002
Syahrul Machmud, Penegakan Hukum dan Perlindungan Hukum bagi Dokter yang diduga Melakukan Medikasi Malpraktek, Cetakan 1, CV Mandar Maju, Bandung, 2008

Tatang M. Amirin, Menyusun Rencana Penelitian, Cet.3, PT Raja Grafindo Persada, Jakarta, 1995

Zainuddin Ali, Metode Penelitian Hukum, Penerbit Sinar Grafika, Jakarta, 2011

\section{Paper/Jurnal/Makalah}

Maskun, Problematika Aplikasi Produk Pemikiran Hukum Islam di Indonesia, dalam Jurnal Bulanan Mimbar Hukum N0. 49, Al Hikmah Ditbinbapera Islam, Jakarta, 2000

Sartika Sasmi Ticoalu, Tanggung Jawab Pemerintah Dalam Memberikan Pelayanan Kesehatan Terhadap Masyarakat, Lex et Societatis, Vol. I/No. 5/September/2013

\section{Internet}

Nila Farid Moeloek, Menteri Kesehatan RI, dalam pidato Pembukaan Simposium Internasional ke-2 Penelitian dan Pengembangan Kesehatan: Basic Research and Innovation Breakthrough into Product, Publikasi dari Pusat Komunikasi Publik Sekretariat Jenderal Kementerian Kesehatan RI Selasa 15 Sepember 2015 di Jakarta. www.depkes.go.id 
Alya Tursina, Terapi Transplantasi Sel Punca Sebagai Upaya Pelayanan Kesehatan Di Indonesia Dalam...

Suryadharma Ali, Menteri Agama RI, dalam pidato Pembukaan, International Conference on Fatwa, Jakarta, 24 - 26 Desember 2012. www.kemenag.go.id diunduh 20 Januari 2016 pukul 21.00

\section{Peraturan Perundang - Undangan}

\section{Pembukaan Undang-Undang Dasar 1945}

Undang-Undang Dasar 1945 Pasal $28 \mathrm{H}$ ayat (1) dan Pasal 34 ayat (3 dan 4)

\section{Undang-Undang}

Undang-Undang No 8 tahun 1999 tentang Perlindungan Konsumen.

Undang-Undang No 18 tahun 2002 tentang Sistem Nasional Penelitian, Pengembangan, Penerapan Ilmu Pengetahuan dan Teknologi.

Undang-Undang No 29 tahun 2004 tentang Praktik Kedokteran.

Undang-Undang Republik Indonesia No. 36 Tahun 2009 Tentang Kesehatan, Fokusmedia, Bandung, 2011

\section{Peraturan Pemerintah}

Peraturan Pemerintah No. 18 tahun 1981 Tentang Bedah Mayat Anatomis serta Transplantasi Alat dan atau Jaringan Tubuh Manusia.

\section{Keputusan Menteri Riset dan Teknologi}

Keputusan Menteri Riset dan Teknologi Republik Indonesia Nomor 193/M/Kp/IV/2010 tentang kebijakan strategis pembangunan nasional ilmu pengetahuan dan teknologi tahun 20102014, ditetapkan tanggal 30 April 2010.

\section{Keputusan Menteri Kesehatan}

Keputusan Menteri Kesehatan Republik Indonesia Nomor 1333/Menkes/SK /XII/1999 tentang Standar Pelayanan Rumah Sakit.

Keputusan Menteri Kesehatan Republik Indonesia Nomor 159/Menkes/SK/II /2009 tentang Penunjukkan RSUP Nasional DR. Ciptomangunkusumo Jakarta sebagai Pusat Penelitian, Pengembangan dan Pelayanan Medis Sel Punca.

Keputusan Menteri Kesehatan Republik Indonesia Nomor 834/Menkes/SK/IX /2009 tentang Pedoman Pelayanan Medis Sel Punca.

Keputusan Menteri Kesehatan Republik Indonesia Nomor 604/Menkes/SK/V /2010 tentang Komite Nasional Sel Punca.

\section{Peraturan Menteri Kesehatan}

Peraturan Menteri Kesehatan Republik Indonesia Nomor 920/MENKES/PER /XII/1986 tentang Upaya Pelayanan Kesehatan Swasta di Bidang Medik.

Peraturan Menteri Kesehatan Republik Indonesia Nomor 269/MENKES/PER /III/2008 tentang rekam medis.

Peraturan Menteri Kesehatan Republik Indonesia Nomor 290/MENKES/PER /II/2008 tentang persetujuan tindakan kedokteran. 
Alya Tursina, Terapi Transplantasi Sel Punca Sebagai Upaya Pelayanan Kesehatan Di Indonesia Dalam...

Peraturan Menteri Kesehatan Republik Peraturan Menteri Kesehatan Republik Indonesia Nomor 833/MENKES/PER Indonesia Nomor 50 tahun 2012 tentang /IX/2009 tentang penyelenggaraan pelayanan penyelenggaraan laboratorium pengolahan sel punca sel punca untuk aplikasi klinis.

Peraturan Menteri Kesehatan Republik Peraturan Menteri Kesehatan Republik Indonesia Nomor 48 tahun 2012 tentang Indonesia Nomor 62 tahun 2013 tentang penyelenggaraan bank sel punca darah tali penyelenggaraan bank jaringan dan atau sel. pusat. 